\title{
ANALÝZA VÝSTAVBY MEMBRÁNOVÉ KONSTRUKCE S OHLEDEM NA ZATÍŽENÍ VĚTREM
}

\author{
CONSTRUCTION STAGES ANALYSIS OF A MEMBRANE STRUCTURE \\ WITH RESPECT TO WIND LOAD
}

\author{
"zajac.z@fce.vutbr.cz \\ ${ }^{1}$ Vysoké učení technické v Brně, Veveři 331/95, 60200 Brno
}

Zbyněk Zajac ${ }^{*}, 1$

\begin{abstract}
Abstrakt
Tento př́spěvek se zabývá analýzou odezvy membránové konstrukce na zatížení větrem s ohledem na fáze výstavby. Moderní nástroje umožn̆ují analýzu odezvy konstrukce na postupné předpínání membrán. Tato úloha byla doposud při posouzení zjednodušována a důkladněji řešena až při návrhu postupu výstavby konstrukce. Tento přístup často vede k zbytečnému předimenzování subtilních prvků, jelikož není možné přesně odhadnout odezvu konstrukce $\mathrm{v}$ př́ípadě neočekávaného zatížení na rozestavěnou konstrukci. Cílem této práce je mimo jiné poukázat na význam výpočtu stavebních fází membránových konstrukcí z důvodu bezpečnosti výstavby.
\end{abstract}

\section{Klíčová slova}

Fáze výstavby, form-finding, membránová konstrukce, zatížení větrem

\begin{abstract}
This paper deals with an analysis of a membrane structure loaded with wind pressure with respect to the construction stages. Modern tools allow analysis of structural response to the prestressing of membrane surfaces in the predefined sequence. So far, analytical models of the membrane structures have been simplified and the sequence of construction has been designed afterwards. This process may lead to the oversized elements, because it is not possible to estimate the structural response to the unexpected load on the structure under construction. Besides, the aim of this paper is to point out the meaning of the construction stages analysis of the membrane structures with respect to the safety on a building site.
\end{abstract}

Key words

Construction stages, form-finding, membrane structure, wind load

\section{1 ÚVOD}

Návrh, analýza, výroba a realizace lehkých membránových konstrukcí je komplexní proces, který vyžaduje odborné zkušenosti a speciální analytické nástroje. V minulosti byla výstavba konstrukcí tohoto typu silně závislá na zkušenostech inženýrů, kteří výstavbu realizovali. Postupně vznikly teorie a př́stupy, které umožnily analýzu větších a důmyslnějších konstrukcí. Také oblast tkaných materiálů dostála vývoje, díky kterému je materiál efektivněji využit, byt' potenciál ještě není zdaleka naplněn.

V dnešní době je již možné s pomocí moderních nástrojů nejen nalézt hledaný tvar konstrukce pro předepsané předpětí, ale také analyzovat podpůrnou konstrukci přenášející zatížení od vneseného předpětí. Analýza konstrukce v jednotlivých stavebních fázích s ohledem na postupné hledání tvaru membránové plochy je dalším nezbytným krokem vývoje, který umožní prověrit stavy konstrukce během předpínání membránových ploch.

Odezva konstrukce na případná neočekávaná zatížení se mění v každé fázi s ohledem na rozestavěnou podobu konstrukce. Předpínání konstrukce nelze kvůli náročnosti na prostor a vybavení provést najednou, proto jsou jednotlivá membránová pole předpínána postupně. Rozestavěná konstrukce je tedy po určitou dobu vystavena povětrnostním podmínkám způsobem, který nemusel být při posouzení zohledněn.

Ačkoli výše uvedená tvrzení platí pro výstavbu každé konstrukce, nabývají většího významu právě u lehkých membránových konstrukcí. V této oblasti není prozatím analýza stavebních fází standardní praxí, jelikož ji doposud obvyklé statické programy neumožňovaly. Podpůrná konstrukce se obvykle skládá z většího počtu subtilních prvků, jejichž rezerva ve statické únosnosti není dostatečně velká a jsou navrženy na přenos určitého 
typu namáhání. Analýza výstavby membránové konstrukce je nezbytný krok při návrhu konstrukce, díky kterému lze předejít problémům, které se mohou na staveništi při výstavbě vyskytnout.

\section{POPIS SOUČASNÉHO POZNÁNÍ}

Podstata návrhu a analýzy membránových konstrukcí spočívá především v nalezení tvaru pro předepsané předpětí, které je vstupním parametrem procesu form-finding. Z podstaty použitého materiálu je ohybová tuhost membránové plochy téměř nulová. Zatížení na membránovou plochu je přenášeno $\mathrm{v}$ tečných rovinách normálovými silami $n_{\mathrm{x}}, n_{\mathrm{y}}$ a smykovými silami $n_{\mathrm{xy}}[1]$.

\section{Form-finding}

Proces hledání tvaru je inverzní problém ke klasické statické analýze, kdy jsou napětí na konstrukci hledanou veličinou. Pro proces form-finding je nutné výsledná napětí předepsat. Napětí je tedy obecně nezávislé na deformaci, ale deformace vycházejí z definovaného napětí. Není tedy závislé na materiálových vlastnostech tkaniny. Platí princip, že tvar následuje sílu.

Metody pro hledání tvaru zaznamenaly v posledních desetiletích rychlý vývoj od lanových sítí až po formulace zahrnující 2D prvky [2]. Existuje zde mnoho překážek, jako např́íklad matematické singularity, se kterými se byli autoři těchto metod nuceni vypořádat [3], [4].

Slabá formulace procesu form-finding vychází z variační formulace principu virtuální práce:

$$
-\delta W=\delta W^{i n t}-\delta W^{e x t}=t \cdot \int_{\Omega} \boldsymbol{\sigma}: \delta \hat{\mathbf{e}} d \Omega-\int_{\Omega} \vec{p} \cdot \delta \mathbf{u} d \Omega=0,
$$

kde $\delta W$ je variace celkové virtuální práce, $\delta W^{\text {int }}$ je variace virtuální práce vnitřních sil, $\delta W^{\text {ext }}$ je variace virtuální práce vnějších sil, $t$ je tloušt'ka materiálu, $\boldsymbol{\sigma}$ je předepsaný Cauchyho tensor napětí, $\delta \hat{e}$ je variace Euler-Almansiho tensoru deformace, $\vec{p}$ je vnější zatížení, $\delta \mathbf{u}$ je virtuální posunutí a $\Omega$ je plocha [5].

\section{Zatížení větrem na membránové konstrukce}

Vyhodnocení účinku zatížení větrem na membránové konstrukce je stále ve stádiu vývoje. Tento typ konstrukcí není zahrnut mezi standardní konstrukce, pro které jsou v platné normě pro zatížení větrem [6] definovány tlakové koeficienty. Standardní postup je tedy vyhodnocení zatížení větrem pomocí CFD analýzy či experimentem ve větrném tunelu [7]. Provádění experimentů je již v dnešní době na ústupu z důvodu časové náročnosti a finanční nákladnosti.

Pro posouzení zatížení větrem na membránové konstrukce je možné využít data publikovaná v obecném doporučení European design guide for tensile surface structures [1]. V publikaci jsou uvedeny hranice oblastí a tlakové koeficienty pro základní tvary membránových konstrukcí jako jsou hyperbolický paraboloid, sedlo či kónický tvar. Hodnoty jsou založeny na výsledcích experimentů provedených ve větrných tunelech.

\section{METODIKA}

Tento př́spěvek navazuje na autorovu diplomovou práci [8], která se zabývá analýzou postupu výstavby konstrukce membránového zastřešení na břehu Labe. Záměrem bylo vyhodnotit postupy pro předepnutí membránové konstrukce a následné odstraňování podélných výztuh. Na Obr. 2 je zachycen výsledný stav hlavních vnitřních sil $n_{1}$ nejvhodnější varianty. Postup předepnutí odpovídá schématu 1-8-3-6-2-7-4-5 dle číslování polí na Obr. 2. Ve stejném pořadí byla následně odstraňována podélná ztužidla konstrukce. Ve výsledné fázi spojuje dřevěné vazníky pouze tenká membránová plocha.

\section{Výpočetní model}

Původní model použitý v diplomové práci byl inspirován membránovým zastřešením tribuny na břehu Labe v Drážd'anech. Dokumentace pro vytvoření modelu na Obr. 1 byla převzata z veřejně dostupného zdroje [9].

Konstrukce se skládá z 8 membránových polí širokých 6,0 m. Celkem je dlouhá 48,0 m, široká 13,5 m a nejvyšší bod je ve výšce $6,5 \mathrm{~m}$. Každý dřevěný vazník je podepřen dvěma ocelovými sloupy ve tvaru písmene $\mathrm{V}$. Pro účely výstavby jsou vazníky rozepřeny čtyřmi podélnými výztuhami. Osm krajních kotevních lan stabilizuje vazníky na okrajích. 


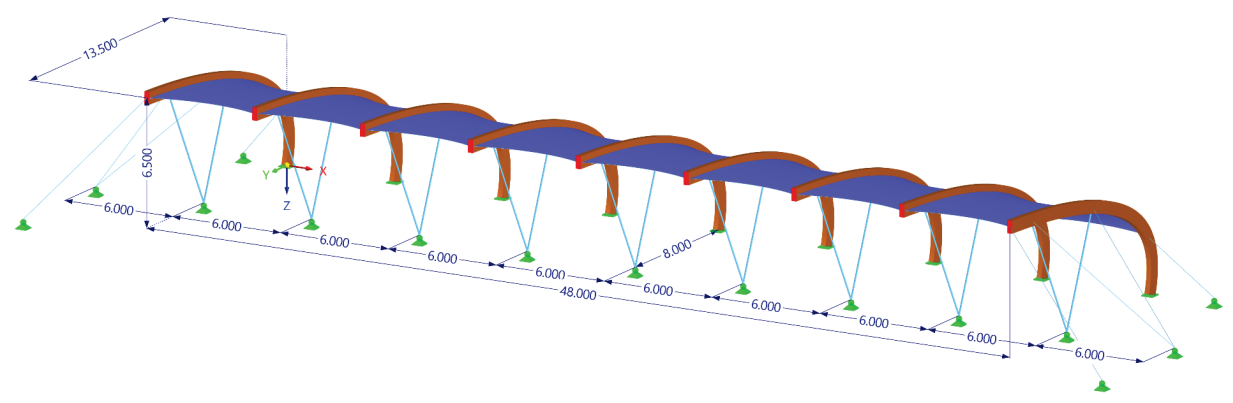

Obr. 1 Výpočetní model membránového zastřešení tribuny.

Tkaný materiál byl zvolen dle platného doporučení [1] PVC typ IV s předepsanými charakteristikami, které se mohou lišit v závislosti na výrobci a výrobním postupu. Důležitou součástí výroby je průběžné testování kvality výrobku. Hustota materiálu je $1300 \mathrm{~g} / \mathrm{m}^{2}$, pevnost v tahu $149 / 128 \mathrm{kN} / \mathrm{m}$ a pevnost ve smyku $1100 / 1400 \mathrm{~N}$. Hodnoty pevnosti v tahu jsou udávány dvojí, v osnově a útku. Rozdílné vlastnosti v závislosti na směru jsou dány výrobním procesem tkaní [10].

\section{Předpětí a fáze výstavby}

Izotropní předpětí $n_{\mathrm{x}}$ a $n_{\mathrm{y}}$ bylo zvoleno $1,5 \mathrm{kN} / \mathrm{m}$. V okrajových lanech ploch byla předepsána průměrná síla $10,0 \mathrm{kN}$. V osmi krajních lanech byla rovněž předepsána průměrná síla $10,0 \mathrm{kN}$, která je do konstrukce vnesena v první fázi, čímž dojde ke zvětšení tlakové únosnosti podélných výztužných prvků.

Vnesení tahu do konstrukce předpětím krajních kotevních lan bylo označeno jako fáze č. 1. Následně ve fázích č. 2 až č. 9 došlo k postupnému napnutí membránových polí. Posledním krokem bylo postupné odstranění podélných výztuh ve fázích č. 10 až č. 17.

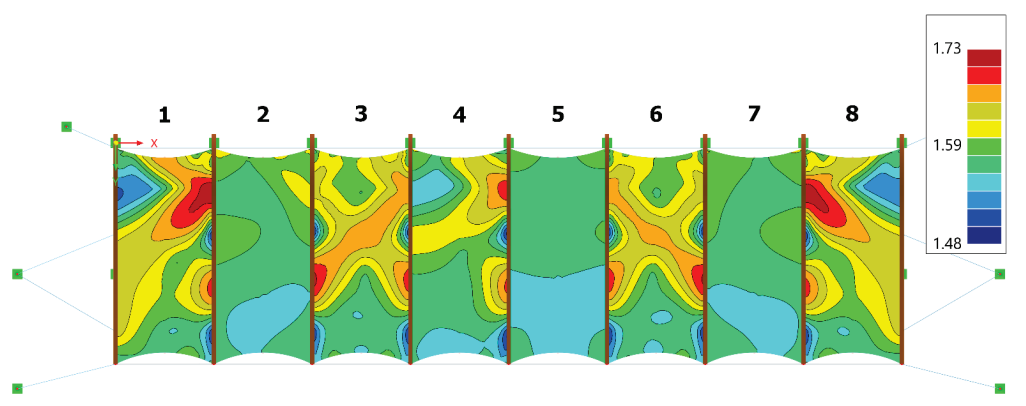

Obr. 2 Rozložení hlavních vnitřních sil $n_{1}(\mathrm{kN} / \mathrm{m})$ nejvhodnější varianty předepnutí konstrukce.

\section{Analýza větrného zatížení}

V rámci práce [8] bylo analyzováno zatížení větrem výsledného stavu vhodnější varianty. Dynamický tlak větru byl stanoven na $1,02 \mathrm{kN} / \mathrm{m}^{2}$. Jednoduchý tvar membránového zastřešení tribuny umožnil převzetí tlakových koeficientů z publikace [1]. Bylo vyhodnoceno, že účinky větru z otevřené strany konstrukce, proti směru globální osy Y, vyvodí na konstrukci větší účinky, než v opačném směru. Při zatížení konstrukce v daném směru dojde k sečtení účinků tlaku na vnitřní stranu plochy a sání na vnější stranu plochy. Výsledné zatížení je zachyceno na Obr. 3.

Tento směr zatížení byl dále analyzován $\mathrm{v}$ jednotlivých stavebních fázích za účelem ověření schopnosti rozestavěné konstrukce přenést neočekávané zatížení. 

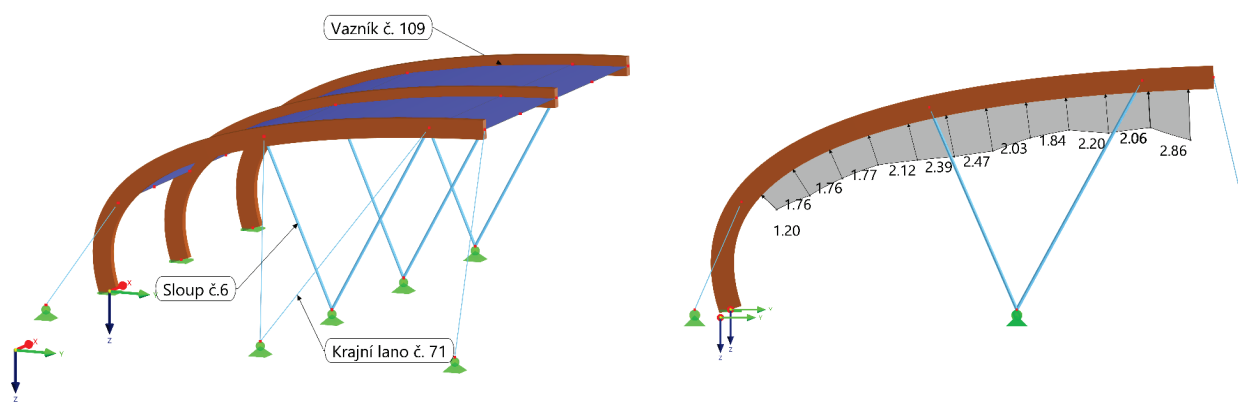

Obr. 3 Analyzované prvky konstrukce a detail zatížení větrem $\left[\mathrm{kN} / \mathrm{m}^{2}\right]$ proti směru osy $\mathrm{Y}$.

\section{VÝSLEDKY ANALÝZY ZATÍŽENÍ VĚTREM}

Byly pozorovány změny vnitřních sil na vybraných prvcích konstrukce zatížené větrem vyznačených na Obr. 3 . Prvky byly vybrány na základě pozorování největších změn mezi fázemi či největšího nárůstu mezi první a poslední fází. Výsledky jsou shrnuty na Obr. 4, kde modré body značí hodnotu zkoumané vnitřní síly v dané fázi. Červená konstantní funkce slouží pro srovnání s výpočtem celé konstrukce bez zohlednění stavebních fází.

Nejprve byl analyzován prvek č. 6. Jedná se o vertikální ocelovou podporu dřevěného vazníku. V první fázi byl namáhán tlakem $-15,88 \mathrm{kN}$. Při napnutí prvního pole dosáhla normálová síla hodnoty $29,61 \mathrm{kN}$ a sloup byl namáhán tahem. V následujících fázích se tah snižoval až na $0,48 \mathrm{kN}$. Postupným odebíráním podélných výztuh od 10. fáze docházelo k navyšování tlakového namáhání až do poslední fáze, kdy nabylo hodnoty $-32,77$ kN.

Pro srovnání byl proveden výpočet konstrukce bez zohlednění stavebních fází. Výsledná hodnota normálové síly v sloupu č. 6 při zatížení větrem na celou konstrukci byla 4,14 kN.
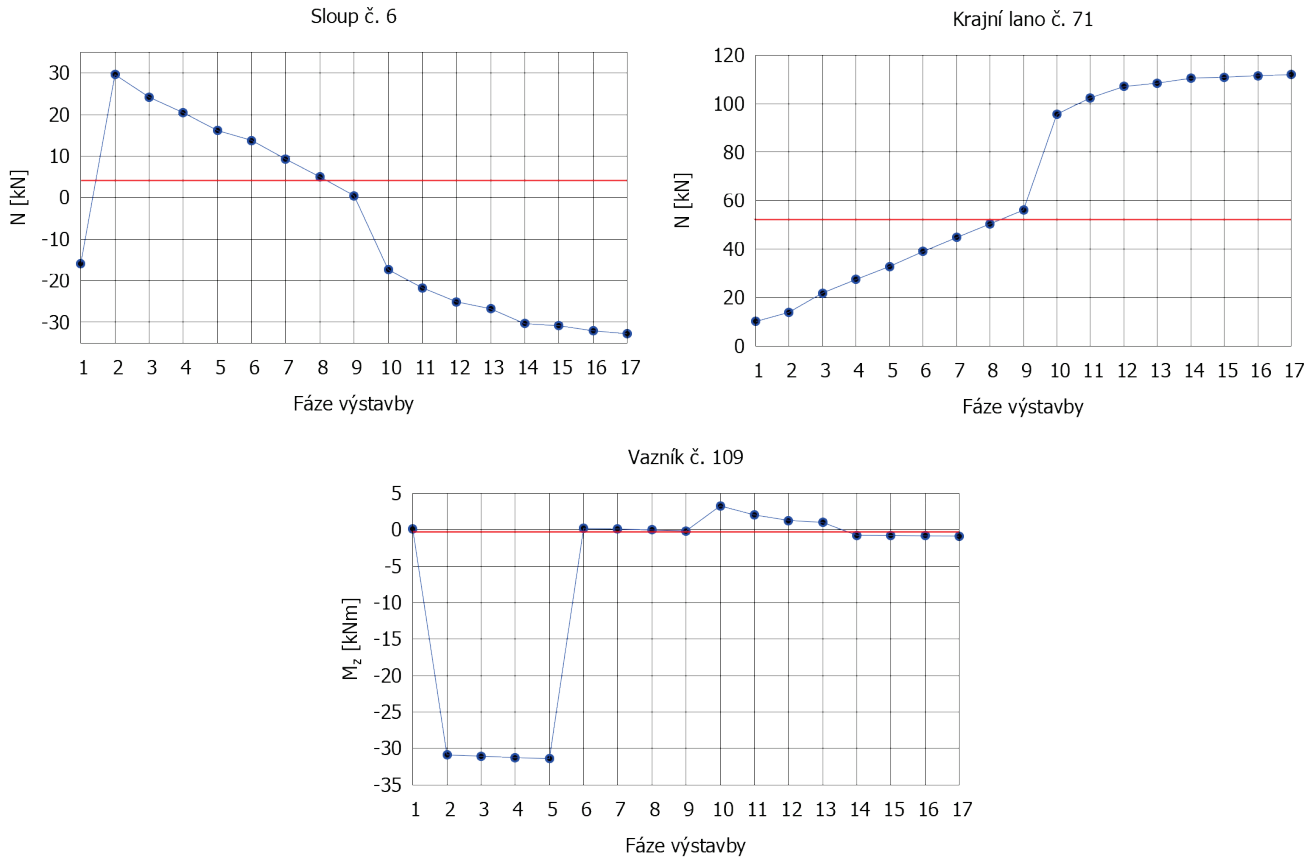

Obr. 4 Hodnoty vnitřních sil od předpětí a zatížení větrem vybraných prvků během výstavby konstrukce. 
Druhým analyzovaným prvkem bylo krajní lano č. 71. Nejprve bylo napnuto v první fázi na $10,08 \mathrm{kN}$. V dalších fázích se při postupném napínáním membránových polí zvětšovala normálová síla v kotevních lanech od předpětí a zatížení větrem. Největší změnu lze pozorovat při odstranění první podélné výztuhy, kdy normálová síla vzrostla skokově na 95,66 kN. Následně síla v laně rostla až na výslednou hodnotu 111,95 kN. Pro srovnání byla v grafu na Obr. 4 vyznačena hodnota normálové síly $52,11 \mathrm{kN}$ na konstrukci nezohledňující výstavbu ve fázích.

Posledním analyzovaným prvkem byl v pořadí třetí vazník č. 109. Na tomto prvku byl zkoumán ohybový moment kolem lokální osy $z$, která na vodorovné části vazníku, kde byly hodnoty zaznamenávány, souhlasí se směrem globální osy $Z$. Tento moment namáhá vazník ve vodorovném směru a je vyvolán zatížením větrem na předepnuté membránové plochy. Ty jsou kotveny ze strany dřevěného lamelového vazníku. Největší moment $\mathrm{M}_{\mathrm{z}}$ nabyl hodnoty $-31,27 \mathrm{kNm}$ a byl zaznamenán v 2. až 5. fázi, kdy došlo k napnutí membránových polí, jejichž okraj tvoří daný vazník. Následně se hodnoty pohybovaly kolem 0 , jelikož byl ohybový moment Mz vyrovnán přidáním sousedního pole. Hodnota ohybového momentu $\mathrm{M}_{\mathrm{z}}-0,31 \mathrm{kNm}$ na konstrukci analyzované bez zohlednění fází výstavby je téměř zanedbatelná.

\section{DISKUZE}

Normálová síla $\mathrm{v}$ ocelovém sloupu č. 6 by se v případě výpočtu bez zohlednění výstavby ve fázích lišila o 28,63 kN. Problém nastal také při zanedbání měnícího se znaménka, jelikož se normálová síla změnila od první do poslední fáze o $63,38 \mathrm{kN}$. V př́ípadě posouzení konstrukčního prvku bez zohlednění fází výstavby by bylo zanedbáno ověření stability tlačeného prvku.

Předepnuté krajní kotevní lano č. 71 zaznamenalo velký nárůst normálové síly při postupném zatěžování. Skokově se síla v laně změnila v desáté fázi o 39,57 kN. Výsledná normálová síla v laně je více než dvakrát větší než při uvažování výpočtu bez stavebních fází.

Pravděpodobně největší problém byl odhalen u lepeného lamelového vazníku č. 109. Analýza postupné výstavby odhalila zanedbání ohybového momentu $\mathrm{M}_{\mathrm{z}}$. Ten ve druhé fázi skokově nabyl hodnoty $-30,9 \mathrm{kNm}$. Následně bylo namáhání v šesté fázi negováno přidáním sousedního membránového pole. Toto namáhání není možné standardní analýzou odhalit a nebylo by zohledněno ve statickém posouzení. S uvážením charakteristik lepeného lamelového dřeva by se jednalo o namáhání pod jiným úhlem vzhledem k uspořádání vláken jednotlivých lamel.

\section{ZÁVĚR}

Výsledky výzkumu potvrdily význam analýzy stavebních fází, který je obecně znám. Nicméně doposud nebyly uvedeny v kontextu lehkých membránových konstrukcí, jelikož tento typ analýzy standardní statické programy doposud neumožňovaly.

Ještě většího významu nabývá analýza stavebních fází při uvážení faktu, že subtilní membránové konstrukce jsou při porušení podpưrné konstrukce či spojující membránové plochy velmi náchylné ke zborcení.

Největším rizikem při zanedbání analýzy stavebních fázích na konstrukci zatížené větrem se ukázaly změna znaménka normálové síly v prvku, neočekávané nárůsty vnitřních sil a opomenuté namáhání dřevěných prvků při postupném předpínání. Tyto změny vnitřních sil by mohly vést k nevratným deformacím na rozestavěné konstrukci zatížené neočekávaným zatížením.

Oblast zatížení membránových konstrukcí větrem je stále z velké části neprobádaná. Ačkoli je zde poptávka po standardizování postupů pro návrh a posouzení, existuje stále mnoho překážek, které bude nutné překonat. V další fázi výzkumu by bylo užitečné provést CFD analýzy a výsledky srovnat s hodnotami získanými z experimentů provedených ve větrném tunelu. V případě dobré shody by bylo možné urychlit získávání dat potřebných pro vytvoření databáze tlakových koeficientů zatížení větru na typické tvary membránových konstrukcí.

\section{Poděkování}

Tento příspěvek byl vytvořen za finanční podpory projektu specifického výzkumu FAST-J-21-7496 Vysokého učení technického v Brně. 


\section{Použité zdroje}

[1] FORSTER, Brian a Marijke MOLLAERT. European design guide for tensile surface structures. Brussel: Tensinet, 2004. ISBN 90-8086-871-X.

[2] VEENENDAAL, D. a P. BLOCK. An overview and comparison of structural form finding methods for general networks. International Journal of Solids and Structures. 2012, 49(26), 3741-3753. ISSN 00207683. Dostupné z: doi:10.1016/j.ijsolstr.2012.08.008

[3] WÜCHNER, R. a K.U. BLETZINGER. Stress-adapted numerical form finding of pre-stressed surfaces by the updated reference strategy. International Journal for Numerical Methods in Engineering. 2005, 64(2), 143-166. ISSN 0029-5981. Dostupné z: doi:10.1002/nme.1344

[4] BLETZINGER, Kai-Uwe a Ekkehard RAMM. A General Finite Element Approach to the form Finding of Tensile Structures by the Updated Reference Strategy. International Journal of Space Structures. 1999, 14(2), 131-145. ISSN 0956-0599. Dostupné z: doi:10.1260/0266351991494759

[5] DIERINGER, Falko Hartmut. Numerical Methods for the Design and Analysis of Tensile Structures. München, 2014. Disertační práce. Technische Universität München.

[6] ČSN EN 1991-1-4 Eurokód 1: Zatížení konstrukci - Část 1-4: Obecná zatížení - Zatižení větrem. Praha: Úřad pro technickou normalizaci, metrologii a státní zkušebnictví, 2013. Tř́ídící znak 730035.

[7] CERMAK, J. E. Studie budov a konstrukci ve větrných tunelech. Praha: Pro Českou komoru autorizovaných inženýrů a techniků činných ve výstavbě (ČKAIT) vydalo Informační centrum ČKAIT, 2009. Technická knižnice (ČKAIT). ISBN 978-80-87093-87-0.

[8] ZAJAC, Zbyněk. Analýza membránových konstrukcís respektováním výstavby ve fázích. Brno, 2021. Diplomová práce. Vysoké učení technické v Brně. Vedoucí práce Rostislav Lang.

[9] Dlubal Software GmbH . Dostupné z: https://www.dlubal.com/en/downloads-andinformation/references/customer-projects/001169

[10] SEIDEL, Michael. Tensile Surface Structures: A Practical Guide to Cable and Membrane Construction. 2009. Berlín. ISBN 978-3-433-02922-0 